\title{
Artikel
}

\section{De effecten van de coronamaatregelen voor mensen met een beperking vanuit een juridisch oogpunt}

\author{
Mr. M. Swaanenburg-van Roosmalen*
}

\section{Vooraf}

In het voorjaar van 2020 greep het nieuwe coronavirus in Nederland om zich heen. Om een dam op te werpen volgde een keur aan maatregelen. Sommige maatregelen namen mensen uit zichzelf al om hun eigen gezondheid of die van anderen te beschermen. Zo meden ze het openbaar vervoer. Ook werd het rustiger bij huisartsenpraktijken en ziekenhuispoli's. Andere adviezen en maatregelen kwamen tot stand in hun omgeving, bijvoorbeeld in hun werkkring of op school. Bedrijven en overheidsinstellingen regelden dat medewerkers niet meer tegelijk in kantoorgebouwen aanwezig waren en schoolreisjes werden uitgesteld. Tot slot waren er adviezen en maatregelen van overheidswege, vooral toen Nederland in een intelligente lockdown ging. Het dagelijks leven veranderde ingrijpend en de samenleving kreeg het predicaat 'anderhalvemetersamenleving'. De gevolgen van dit alles voor de lange termijn tekenen zich af, maar laten zich grotendeels nog raden. Dit geldt temeer nu - op het moment van schrijven, in het vroege najaar - uit testen blijkt dat een toenemend aantal mensen het coronavirus onder de leden heeft.

Deze bijdrage gaat vanuit een juridisch oogpunt in op de effecten van coronamaatregelen van het voorjaar en de zomer van 2020 voor mensen met een beperking. Dit juridische oogpunt omvat alle regelgeving die op mensen met een beperking betrekking heeft, waaronder de Grondwet, verdragen en wetgeving met bevoegdheden en waarborgen ter zake zoals de Wet publieke gezondheid, de Gemeentewet en de Wet veiligheidsregio's. Het $\mathrm{VN}$-verdrag inzake de rechten van personen met een handicap (het VN-verdrag Handicap) neemt in dit geheel een bijzondere plaats in, omdat het specifiek ziet op fundamentele rechten van mensen met een beperking, het nog maar sinds enkele jaren voor (organen van) Nederlandse overheden bindend is en het verdrag een interpretatieve werking heeft. Dit artikel zal daarom inzicht geven in de aspecten die bij het beoordelen van coronamaatregelen in juridische zin van bijzonder belang zijn.

Hierna volgt eerst een schets van het perspectief dat het VN-verdrag Handicap biedt (par. 2). Bijzondere aandacht gaat uit naar de verplichting tot het voeren van nauw overleg met mensen met een beperking en hun (representatieve) organisaties en naar de betekenis van het verdrag in risicovolle situaties. Daarna vindt een aantal onderwerpen bespreking op het terrein van onder meer wetgeving en beleid en door het privaatrecht beheerste contexten (par. 3). In chronologische volgorde betreft het (crisis)communicatie, de corona-app, maatregelen in winkels en de tijdelijke coronawet (Tijdelijke wet maatregelen COVID-19). Dit artikel sluit af met enige meer algemene aandachtspunten voor het nemen en uitvoeren van coronagerelateerde maatregelen gelet op het $\mathrm{VN}$-verdrag Handicap (par. 4). 


\section{VN-verdrag Handicap}

\subsection{In vogelvlucht}

Het VN-verdrag Handicap van 13 december 2006 heeft sinds 14 juli 2016 gelding voor Nederland. ${ }^{1}$ Het verdrag werkt al deels door in wet- en regelgeving. Toen Nederland het verdrag ratificeerde, is ook uitvoeringswetgeving tot stand gebracht, bijvoorbeeld tot wijziging van de Wet gelijke behandeling op grond van handicap of chronische ziekte (WGBH/CZ). ${ }^{2}$ Het verbod van discriminatie op grond van handicap of chronische ziekte geldt sindsdien ook bij het aanbieden van goederen en diensten (art. 5b WGBH/CZ). Vier jaar na dato blijkt de uitvoering van het verdrag een voorwerp van aanhoudende zorg te zijn. ${ }^{3}$ Deze terminologie ${ }^{4}$ is ontleend aan artikel 23 lid 1 Grondwet (over onderwijs) en is eerder in relatie tot de hele Grondwet gebruikt, ${ }^{5}$ maar de zegswijze is zeker ook toepasselijk op de uitvoering van het $\mathrm{VN}$-verdrag Handicap in Nederland.

Het VN-verdrag Handicap beoogt te bevorderen dat mensen met een beperking op voet van gelijkheid (met mensen zonder beperking) alle mensenrechten en fundamentele vrijheden volledig kunnen genieten. Ook heeft het verdrag tot doel om de eerbiediging van de inherente waardigheid van deze mensen (inclusief kinderen $\left.^{6}\right)$ met verschillende beperkingen ${ }^{7}$ te bevorderen (art. $1 \mathrm{VN}$-verdrag Handicap). Deze doelen vertalen zich in een aantal grondbeginselen die als richtsnoer gelden bij de uitleg en uitvoering van het verdrag (art. 3 VN-verdrag Handicap). Daartoe behoren onder meer persoonlijke autonomie, non-discriminatie en toegankelijkheid. In lijn met deze grondbeginselen bevat het verdrag een reeks algemene verplichtingen en rechten.

\subsection{Participatie}

Tot de algemene verplichtingen van staten die partij zijn bij het VN-verdrag Handicap behoort de plicht voor overheden om met mensen met een beperking, met inbegrip van kinderen met een beperking, in nauw overleg te gaan bij de ontwikkeling en implementatie van wetgeving en beleid die het verdrag uitvoeren én bij andere besluitvormingsprocessen die op hen betrekking hebben (art. 4 lid 3 VN-verdrag Handicap). Deze verplichting geldt ook in coronatijd (zie ook hierna in

1. Trb. 2014, 113.

2. Wet van 3 april 2003 zoals laatstelijk gewijzigd bij wet van 17 april 2019.

3. College voor de Rechten van de Mens (CRM), Rapportage aan het Comité voor de rechten van personen met een handicap 2018, 3 december 2018 (hierna: CRM-rapport), https://mensenrechten.nl/nl/ publicatie/38664, ter uitvoering van art. 33 lid 2 VN-verdrag Handicap; Alliantie VN-verdrag Handicap, Schaduwrapportage Verdrag inzake de rechten van personen met een handicap in Nederland, 3 december 2019, iederin.nl/wp-content/uploads/2019/12/Schaduwrapport-VNverdrag-Handicap.pdf.

4. Daarmee bedoel ik dat de uitvoering van het verdrag blijvend om zorg (in de zin van aandacht en inzet) vraagt.

5. J.B.J.M. ten Berge, De Grondwet als voorwerp van aanhoudende zorg (Beurskens-bundel). Zwolle: W.E.J. Tjeenk Willink 1995.

6. Zie onder meer art. $7 \mathrm{VN}$-verdrag Handicap.

7. Langdurige fysieke, intellectuele, mentale of zintuigelijke beperkingen (art. 1 VN-verdrag Handicap). par. 2.3) ${ }^{8}$ Niet alleen (organen van) de rijksoverheid, maar ook (organen van) lagere overheden hebben deze verplichting. Juridisch is de redenering daarbij dat ieder overheidsambt of -orgaan verdragsbepalingen na moet leven voor zover dit passend is binnen zijn taken en bevoegdheden. ${ }^{9}$ Ook moet met verdragen zo veel mogelijk rekening worden gehouden bij de uitleg en toepassing van wettelijke voorschriften. ${ }^{10}$ Tot slot kunnen verdragsbepalingen de beleidsvrijheid van uitvoerende instanties normeren. ${ }^{11}$ Juist in de coronatijd, waarin overheidsmacht de facto verschuift in de richting van regionale en lokale bestuursorganen, is dit een belangrijk punt.

Uit het voorgaande volgt dat de verplichting om actief nauw overleg te plegen met mensen met een beperking en hun organisaties niet alleen geldt wanneer bijvoorbeeld op rijksniveau een corona-app tot ontwikkeling wordt gebracht (zie hierna par. 3.2) of een tijdelijke wet over coronamaatregelen wordt voorbereid (zie hierna par. 3.4). Gemeentelijke organen moeten aan deze verplichting ook gevolg geven, bijvoorbeeld wanneer ze als wegbeheerder optreden of bevoegdheden uitoefenen ten aanzien van de openbare ruimte, bijvoorbeeld bij het aanbrengen van looproutes in winkelstraten. Omdat het $\mathrm{VN}$-verdrag Handicap via wetgeving kan doorwerken in de rechtsverhouding tussen private partijen en mensen met een beperking, is het belangrijk dat er tussen hen overleg is. Denk aan de verplichting die op aanbieders van goederen en diensten rust om geleidelijk te komen tot algemene toegankelijkheid (art. 2a jo. art. 5b WGBH/CZ) en aan de inkleuring van (privaatrechtelijke) zorgplichten (vgl. art. 6:162 BW).

\subsection{Risicovolle situaties}

De rechten in het VN-verdrag Handicap hebben voor een groot deel een programmatisch karakter. Ze schrijven voor dat (en hoe) de overheid moet handelen om de rechten in het verdrag voor mensen met een beperking te realiseren. Dat kan veelal geleidelijk, zoals artikel 4 lid 2 VN-verdrag Handicap beschrijft. Het verdrag schrijft bijvoorbeeld voor dat de algemene toegankelijkheid van de samenleving actief moet worden verbeterd (art. 9 $\mathrm{VN}$-verdrag Handicap). Dit betekent onder meer dat de overheid de algemene toegankelijkheid geleidelijk verbetert en waar nodig specifieke maatregelen treft. ${ }^{12}$ De bescherming van het $\mathrm{VN}$-verdrag Handicap strekt zich nadrukkelijk uit tot risicovolle situaties. Artikel $11 \mathrm{VN}-$ verdrag Handicap ziet daar specifiek op. ${ }^{13}$ Onder de

8. Zie ook mensenrechten. $\mathrm{nl} / \mathrm{nl} /$ toegelicht/betrek-mensen-met-eenbeperking-bij-plannenanderhalvemetersamenleving.

9. KB 19 februari 1993, AB 1993, 385 en KB 11 september 2007, Stb. 2007, 347.

10. HR 3 maart 1919, NJ 1919, 371

11. Kamerstukken I/ 2013/14, 33992 (R034), nr. 4, punt 3

12. Over de band van de WGBH/CZ rust op de aanbieders van goederen en diensten ook de verplichting om maatregelen te nemen voor risicovolle situaties zoals brand en evacuaties. Vgl. CRM, Jaarlijkse rapportage over VN-verdrag voor de rechten van personen met een handicap 2019, 3 december 2019, p. 21.

13. Zie voor de totstandkoming en de achtergronden van dit artikel: I. Bantekas e.a. (red.), The UN Convention on the Rights of Persons with Disabilities: A Commentary, Oxford: Public International Law 2018. 
werking van het artikel vallen crisissituaties en (humanitaire) noodsituaties, variërend van conflictsituaties tot natuurrampen.

Ik ben van mening dat een pandemie met (een vorm van) lockdown ook als een dergelijke situatie is aan te merken. Het artikel verplicht verdragsstaten om alle nodige maatregelen te nemen om de bescherming en veiligheid van mensen met een beperking in risicovolle situaties te waarborgen. Het is aangewezen dat de overheid met voorrang werkt aan maatregelen gericht op risicovolle situaties, omdat deze naar hun aard ernstig zijn. Dit geldt temeer daar er eerder al heldere signalen waren dat het daar in Nederland nog aan schort. Zo heeft het College voor de Rechten van de Mens (verder: het College) in 2018 in zijn rapportage aan het VNcomité een opmerking gemaakt over toegankelijkheid van het alarmnummer voor mensen met een auditieve beperking $^{14}$ en uitte de Alliantie VN-verdrag Handicap in haar schaduwrapportage uit 2019 zorgen over crisiscommunicatie rond een dodelijke schietpartij in een tram in Utrecht in het voorjaar van dat jaar. ${ }^{15}$ Toen de pandemie uitbrak, klemde dit alles temeer. Het coronavirus was vrij plotseling in ons land en dat leidde tot een risicovolle situatie bij uitstek (zie ook hierna, par. 3.1).

Het VN-verdrag Handicap bevat geen afzonderlijke bepaling over afwijking van het verdrag in geval van een noodtoestand (vgl. bijvoorbeeld art. 15 EVRM), zij het dat de verplichting in artikel $11 \mathrm{VN}$-verdrag Handicap geldt in overeenstemming met de verplichtingen van verdragsstaten uit hoofde van het internationale recht, met inbegrip van het internationale humanitaire recht en internationale mensenrechtenverdragen. Artikel 11 VN-verdrag Handicap heeft overigens geen rechtstreekse werking en volgens de regering (in haar toelichting bij de goedkeuringswet) leidt de bewoording van het artikel er ook niet toe om rechtstreekse werking aan te nemen. ${ }^{16}$ Dit betekent dat het waarschijnlijk niet met succes in procedures bij de rechter kan worden ingeroepen (vgl. art. 94 Grondwet). Zoals hierboven aangestipt, betekent dit echter niet dat overheden aan het in dit artikel bepaalde voorbij kunnen gaan. Aan het juridisch bindend karakter van de verplichting doet dit alles immers niet af.

\subsection{Toezicht in coronatijd}

Internationaal houdt het VN-comité toezicht op de naleving van dit verdrag. Het comité zou in maart zelf een sessie houden in Genève, maar heeft deze toen noodgedwongen uitgesteld vanwege de uitbraak van de pandemie. Richtinggevend voor de beoordeling van coronamaatregelen vanuit juridisch perspectief is de verklaring van het comité van 9 juni 2020. Daarin stelt het comité dat beslissende en urgente actie vereist is om te verzekeren dat zij die het grootst risico lopen, met inbegrip van mensen met een beperking, expliciet deel uitmaken van overheidsplannen inzake noodsituaties, gezondheidsmaatregelen en herstelmaatregelen. Discri-

\footnotetext{
14. Zie CRM-Rapport, p. 19

15. Zie eveneens CRM-Rapport, p. 21

16. Kamerstukken // 2013/14, 33992 (R2034), nr. 3, p. 43.
}

minatie en ongelijkheid moeten in alle maatregelen uitgesloten worden. Bovendien is de huidige tijd volgens het comité geschikt om te werken aan mechanismen die in de toekomst snel kunnen inspelen op gezondheidscrisissituaties op een wijze 'die niemand achterlaat'. ${ }^{17}$

Nationaal is het toezicht op de uitvoering van het verdrag toebedeeld aan het College. ${ }^{18}$ Sinds de uitbraak van de crisis heeft het College nauwlettend aandacht voor de gevolgen van de coronacrisis voor de naleving van de mensenrechten. Als toezichthouder op het VN-verdrag Handicap beschermt, bevordert en monitort het College de uitvoering van dit verdrag. Dit doet het met betrokkenheid en volledige participatie van het maatschappelijke middenveld (art. 33 lid 3 VN-verdrag Handicap). Sinds de lockdown heeft het College als nationale toezichthouder in overleg met mensen met een beperking en organisaties een serie concrete, toezichthoudende activiteiten ontplooid. ${ }^{19}$ De onderwerpen waar deze activiteiten betrekking op hebben, komen voor een deel aan de orde in de volgende paragraaf.

\section{Coronamaatregelen nader belicht}

\subsection{Crisiscommunicatie}

Op maandag 9 maart 2020 stond naast premier Rutte en RIVM-directeur Van Dissel nog géén tolk Nederlandse Gebarentaal (NGT) tijdens de live-persconferentie over het coronavirus. Dit was niet in lijn met het VN-verdrag Handicap, want daaruit volgt dat de overheid maatregelen moet nemen om mensen met een beperking in staat te stellen om zelfstandig informatie over crisisen noodsituaties te kunnen zoeken en ontvangen en dat daarbij rekening moet worden gehouden met de communicatievoorkeuren van mensen met een beperking. Zeker in deze beginperiode was het belangrijk dat dit juridische kader belicht werd. ${ }^{20}$ Zo stuitten mensen met een auditieve beperking bij het inwinnen van publieke informatie over het coronavirus ook op barrières en gaven mensen met een verstandelijke beperking aan de informatie over het coronavirus ingewikkeld te vinden.

De verdragsrechtelijke verplichtingen vloeien voort uit het volgende. Toegankelijkheid is een van de grondbeginselen genoemd in artikel $3 \mathrm{VN}$-verdrag Handicap en is als recht opgenomen in artikel 9. De overheid moet passende maatregelen nemen om toegankelijkheid voor

17. VN-comité (CRPD), Statement on COVID-19 and the human rights of persons with disabilities, 9 juni 2020, www.ohchr.org/EN/NewsEvents/ Pages/DisplayNews.aspx?NewsID=25942\&LangID=E.

18. Kamerstukken // 2013/14, 33992-(R2034), nr. 3.

19. Het College kan in het licht van zijn oordelende taak op het terrein van het gelijkebehandelingsrecht op verzoek binnen de reikwijdte van de WGBH/CZ oordelen geven over individuele discriminatieklachten van mensen met een beperking die ook coronagerelateerd kunnen zijn. Op het moment van schrijven heeft het College nog geen oordelen uitgebracht die specifiek met coronamaatregelen te maken hebben.

20. CRM 11 maart 2020, 'Toegankelijke informatie en communicatie in risicovolle situaties', mensenrechten. $\mathrm{nl} / \mathrm{nl} /$ toegelicht/toegankelijkeinformatie-en-communicatie-risicovolle-situaties. 
mensen met een beperking op voet van gelijkheid met anderen te garanderen, waaronder toegankelijkheid van informatie en communicatie. De algemene toegankelijkheid van de samenleving vergt dat de overheid de algemene toegankelijkheid voor mensen met een beperking geleidelijk verbetert en waar nodig specifieke maatregelen treft. Omdat risicovolle situaties naar hun aard ernstig zijn, ligt het voor de hand dat de overheid met voorrang werkt aan maatregelen gericht op die situaties. Zoals hiervoor aangestipt, ziet artikel $11 \mathrm{VN}$ verdrag Handicap op risicovolle situaties en dit artikel verplicht verdragsstaten ertoe om alle nodige maatregelen te nemen om de bescherming en veiligheid van mensen met een beperking in risicovolle situaties te waarborgen. Van belang daarbij is artikel $21 \mathrm{VN}-\mathrm{ver}-$ drag Handicap over toegang tot informatie door middel van communicatiemiddelen naar keuze van mensen met een beperking. Verdragsstaten moeten maatregelen nemen om voor het publiek bedoelde informatie tijdig en zonder extra kosten te verschaffen in toegankelijke vormen en met technologieën die geschikt zijn voor de verschillende soorten beperkingen. Uit deze artikelen samen volgt dat de overheid maatregelen moet nemen zodat mensen met een beperking, zoals een zintuiglijke of intellectuele beperking, informatie krijgen in risicovolle situaties op een wijze die aansluit bij hun communicatievoorkeuren, bijvoorbeeld informatie in Nederlandse gebarentaal, een schrijftolk of audiodescriptie.

Sinds 9 maart 2020 is er in ieder geval bij de persconferenties over het coronavirus het een en ander veranderd. Zo werd tolk NGT Irma Sluis voor een breed publiek een vertrouwde verschijning aan de zijde van de betrokken bewindslieden. Er is ook ruim aandacht voor informatie in eenvoudige taal. ${ }^{21}$ Maar het hier geschetste juridische beoordelingskader blijft relevant en actueel voor het uitbrengen van iedere nieuwe coronamaatregel en de verplichting om mensen met een beperking te blijven betrekken duurt onverminderd voort (art. 4 lid 3 VN-verdrag Handicap). ${ }^{22}$

\subsection{Corona-app}

Bij de ontwikkeling van een corona-app in april 2020 was er aandacht voor de impact van de app voor mensen, onder wie mensen met een beperking. Opvallend was dat het VN-verdrag Handicap niet expliciet als onderdeel van het relevante juridische kader naar voren kwam. Het College voor de Rechten van de Mens vroeg daar aandacht voor in een spoedadvies over de plannen voor een corona-app. De minister van Volksgezondheid, Welzijn en Sport (VWS) had daar om gevraagd. ${ }^{23}$

Het VN-verdrag Handicap behoort nadrukkelijk tot het relevante juridische kader. Wetten, waaronder de Wet publieke gezondheid, moeten in het licht van dat ver-

21. Zie bijvoorbeeld corona.steffie. $\mathrm{nl} / \mathrm{nl} /$.

22. Vgl. punt 1 van de brief van de minister van VWS aan de Voorzitter van de Tweede Kamer d.d. 1 september 2020, www.rijksoverheid.nl/ documenten/kamerstukken/2020/09/01/kamerbrief-over-lessencoronamaatregelen-gehandicaptenzorg.

23. CRM 20 april 2020, Spoedadvies aan de minister van VWS over het aanbouwdocument juridische verantwoording corona-apps, mensenrechten.nl/nl/publicatie/5e9d7ff51e0fec037359c1da. drag worden uitgelegd. Ook bij het ontwikkelen van een corona-app moet rekening worden gehouden met de verschillende communicatievoorkeuren van mensen met een beperking. Dit geldt voor het gebruik van de app zelf en voor informatie daarover. Dit alles gold volgens het College des te sterker, omdat veel mensen met een beperking ook tot de groep behoren die in het bijzonder kwetsbaar kan zijn bij besmetting met het virus.

Een punt dat het College eveneens in zijn spoedadvies naar voren bracht, was dat veel mensen met een handicap ermee te maken kregen dat coronamaatregelen ter bescherming van de volksgezondheid niet ten volle voor hen kunnen gelden. Mensen met fysieke beperkingen die voor hun algemene dagelijkse levensverrichtingen afhankelijk zijn van de zorg van anderen kunnen bijvoorbeeld geen anderhalve meter afstand houden, al zouden ze het willen. Het College redeneerde dat een dergelijke slimme, gerichte (digitale) maatregel zou kunnen bijdragen aan de veiligheid en gezondheid van personen met een beperking.

\subsection{Maatregelen in winkels}

Als toezichthouder op de uitvoering van het VN-verdrag Handicap in Nederland en na afstemming met mensen met een beperking en hun organisaties heeft het College tussen 14 mei en 14 juni 2020 een meldpunt 'Goed Toegankelijk' opengesteld. ${ }^{24}$ Mensen konden per telefoon of via een website problemen en oplossingen melden. Dit meldpunt bood inzicht in problemen die mensen met een beperking ervaren met toegankelijkheid tijdens de coronacrisis. Van de 147 meldingen die het College ontving, ging een groot deel over de toegankelijkheid van winkels zoals supermarkten, drogisterijen en andere detailhandel. ${ }^{25}$

Deze meldingen gingen over de fysieke toegankelijkheid van de winkel, over informatie en communicatie, service en begeleiding. Voorbeelden betreffen verplichte winkelwagens en -mandjes, niet-voelbare richting- en afstandsaanduidingen op de vloer van winkels, geluidsbelemmerend of niet zichtbaar afgebakend plexiglas en het niet toestaan van begeleiding. Meldingen over digitaal winkelen kreeg het College verhoudingsgewijs niet heel veel. Dat is opvallend, omdat het beeld bestaat dat in coronatijd juist veel transacties online zijn gedaan. ${ }^{26}$ Uit de uitkomsten van het meldpunt trok het College de conclusie dat er in de anderhalvemetersamenleving werk aan de winkel was. Het College riep de detailhandel op tot het waarborgen van toegankelijkheid in 'coronaprotocollen', in het bijzonder het protocol 'Verantwoord Winkelen'. ${ }^{27}$ Het College wees wederom op het belang van participatie van organisaties

24. Zie mensenrechten. $\mathrm{nl} / \mathrm{nl} /$ goedtoegankelijk.

25. Lees meer over de meldingen en uitkomsten van het meldpunt op mensenrechten.nl/nl/na-sluiting-van-het-meldpunt-goed-toegankelijkwerk-aan-de-winkel.

26. Vgl. echter CRM, Jaarlijkse rapportage over VN-verdrag voor de rechten van personen met een handicap 2019, 3 december 2019 waarin het College concludeerde dat digitale toegankelijkheid rond het aanbieden van goederen en diensten meer aandacht moet krijgen.

27. Zie www.rijksoverheid.nl/documenten/publicaties/2020/03/25/ protocol-verantwoord-winkelen. 
door en voor mensen met een beperking. In dit verband is de doorwerking van artikel 4 lid 3 VN-verdrag Handicap in privaatrechtelijke rechtsbetrekkingen relevant. Zie daarvoor ook paragraaf 2.2.

De tips voor ondernemers die MKB-Nederland opstelde in samenwerking met onder meer de Oogvereniging, Koninklijke Visio en Bartiméus, ${ }^{28}$ zijn vanuit juridisch oogpunt positief. De 15 tips sluiten overwegend goed aan bij het VN-verdrag Handicap, maar zelfstandigheid is een belangrijk uitgangspunt van het verdrag en zou daarom ook centraal moeten staan. Het aanbieden van begeleiding is volgens het College bijvoorbeeld, gelet op het verdrag, geen alternatief voor aanpassingen die mensen met een beperking buiten de coronasituatie in staat stellen om zelfstandig te winkelen.

\subsection{Tijdelijke wet maatregelen COVID-19}

Sinds maart 2020 nemen de veiligheidsregio's de maatregelen voor de bestrijding van het coronavirus op in zogenoemde noodverordeningen, gericht op (crisis)situaties die beperkt zijn in duur. Omdat de coronacrisis aanhoudt, houdt de wetgever zich bezig met ontwerpwetgeving ter vervanging van noodverordeningen door de tijdelijke coronawet (Tijdelijke wet maatregelen COVID-19). ${ }^{29}$ Een consultatieversie van het wetsvoorstel werd daartoe voorgelegd aan verschillende (advies)organen, bestuurlijke partners en andere instanties, waaronder het College voor de Rechten van de Mens. Het College adviseerde over mensenrechten in brede zin, maar ook als toezichthouder op de uitvoering van het VN-verdrag Handicap in Nederland. ${ }^{30}$

Een belangrijke opmerking die het College in dat verband makkte is dat het een meer algemene beschouwing over de verhouding van het wetsvoorstel tot het $\mathrm{VN}$ verdrag Handicap in (de consultatieversie van) de memorie van toelichting miste. Daaraan bestond volgens het College temeer behoefte, omdat de voorlichting over grondwettelijke aspecten van (voor)genomen crisismaatregelen door de Afdeling advisering van de Raad van State, waarnaar de toelichting verwees, zich had beperkt tot de Grondwet, het EVRM en het EUHandvest. ${ }^{31}$ Een eigenstandige toelichting op het voorstel in het licht van het VN-verdrag Handicap, zo betoogde het College, is wenselijk omdat wetgeving, met inbegrip van de Wet publieke gezondheid, in het licht van dit verdrag moet worden uitgelegd. Ook doet een dergelijke beschouwing in die zin recht aan het feit dat mensen met een beperking onder dit verdrag mensenrechten hebben die relevant zijn voor verschillende besluitvormings- en beoordelingsprocessen waarvoor het voorstel een basis legt.

28. Zie www.mkbtoegankelijk.nl/anderhalvemetersamenleving.

29. Kamerstukken II 2019/20, 35526, nr. 2. Vgl. ook AARvS 25 mei 2020 , voorlichting over de grondwettelijke aspecten van (voor)genomen crisismaatregelen, nr. W04.20.0139/I/Vo), § 11.

30. CRM 3 juni 2020, Aandachtspunten bij het voorstel voor een Tijdelijke wet maatregelen COVID-19 (spoedadvies), mensenrechten. $\mathrm{nl} / \mathrm{nl} /$ publicatie/5ed908751e0fec037359c284.

31. AARvS, voorlichting van 25 mei 2020, zaak nr. W04.20.0139/I/Vo.
Mede daarom is het belangrijk om te constateren dat de memorie van toelichting die na de consultatie bij het wetsvoorstel is gevoegd, ${ }^{32}$ ingaat op het $\mathrm{VN}$-verdrag Handicap in meer algemene zin. ${ }^{33}$ De regering erkent dat de maatregelen ter bestrijding van de epidemie ook impact hebben op het leven van mensen met een beperking: 'Bij het opstellen van het wetsvoorstel is hun positie vanzelfsprekend in ogenschouw genomen.' Dat het daarbij ook om het VN-verdrag Handicap gaat, blijkt uit de plaats van het verdrag in het hoofdstuk over grondrechtelijke aspecten (par. 5.10.). 'Mede in het licht van het verdrag' acht de regering het wenselijk om voor de begeleiding van personen met een beperking al op wetsniveau te voorzien in een uitzondering op de veiligeafstandsnorm ${ }^{34}$ en kunnen mensen met een beperking en hun begeleider of begeleiders ook geen eventueel te verbieden groep vormen. ${ }^{35}$ Daarvoor is aangesloten bij het begrip 'personen met een handicap' zoals opgenomen in het verdrag: deze mensen en hun begeleiders behoeven ten opzichte van elkaar geen veilige afstand te bewaren, indien dat niet mogelijk is. Verder volgt uit het bestanddeel 'zich ophouden' in de veiligeafstandsnorm dat kortstondige handelingen, zoals de situatie waarin een persoon met een visuele beperking een andere persoon passeert of de situatie waarin een persoon met een beperking wordt geholpen met in- of uitstappen, niet onder de norm vallen.

Met deze toelichting lijkt geborgd te zijn dat de uitzondering niet slechts geldt voor personen die vanwege hun fysieke beperking geen veilige afstand kunnen bewaren tot hun begeleider, omdat zij bijvoorbeeld gebruik maken van een rolstoel, maar ook kan gelden voor personen met een verstandelijke beperking die vanwege hun beperking de norm niet begrijpen dan wel onthouden waardoor ze niet de hele tijd afstand houden. Ook lijkt eruit te volgen dat de uitzondering van toepassing is, wanneer mensen met een beperking hulp krijgen van derden, bijvoorbeeld in het openbaar vervoer. Dat waren punten waarvan het College in ieder geval had gesteld dat verduidelijking ervan de toelichting ten goede zou komen.

\section{Ter afsluiting}

In deze bijdrage kwamen de coronamaatregelen van het voorjaar van 2020 aan de orde. Na de voorjaarsmaatregelen volgden minder ingrijpende zomermaatregelen. Het najaar van 2020 voegde een nieuw hoofdstuk aan dit geheel van coronamaatregelen toe. In deze bijdrage kwam naar voren dat de voorjaars- en zomerse coronamaatregelen zeer divers zijn geweest (zoals publiek of privaat) en voor mensen met een beperking verschillend hebben kunnen uitpakken, al naar gelang hun omstandigheden, waaronder ook de plaats waar zij

\footnotetext{
Derde herdruk.

Kamerstukken // 2019/20, 35526, nr. 3, p. 37-38.

Art. $58 \mathrm{f} \mathrm{lid} 3$ onder $d$ van het wetsvoorstel.

Art. $58 \mathrm{~g}$ lid 2 onder a van het wetsvoorstel.
} 
wonen, werken en onderwijs volgen. Wat dat laatste betreft: denk aan mensen met een beperking die in de zomer soms wel en soms nog steeds niet naar hun dagbesteding konden gaan of die in een Wlz-instelling wonen waar ze nog of weer geen bezoek konden ontvangen vanwege het virus. Een deel van de mensen met een beperking behoort, in relatie tot het nieuwe coronavirus, tot een risicogroep en dringt aan op stringente maatregelen, terwijl een ander deel wil en kan deelnemen aan de samenleving en daarbij obstakels tegenkomt. Weer een ander deel is content met bepaalde coronamaatregelen als die voor het thuiswerken, een maatregel die voor sommige mensen met bijvoorbeeld een (psychosociale) beperking een uitkomst is.

Hoe verschillend individuele situaties van mensen met een beperking ook kunnen zijn, bij alle maatregelen rond corona moeten juridische analyses de rechten van mensen met een beperking betrekken: niet alleen in het licht van de Grondwet en wetgeving met waarborgen ter zake, maar ook in het licht van mensenrechtenverdragen en dan vooral het VN-verdrag Handicap. Het is dan ook terecht dat de regering daar wat betreft de Tijdelijke wet maatregelen COVID-19 uiteindelijk toch oog voor heeft gehad.

Deze bijdrage belichtte dat het VN-verdrag Handicap in coronatijd onverminderd van kracht is en dat uit het verdrag volgt dat nauw overleg met mensen met een beperking en hun (representatieve) organisaties ook bij de totstandkoming van coronamaatregelen geboden is. Ook heeft deze bijdrage voor verschillende concrete coronamaatregelen aangegeven welke aspecten bij het beoordelen daarvan, gezien het VN-verdrag Handicap, in het bijzonder van belang zijn. Daarbij kwam bij verschillende maatregelen terug dat er in de praktijk nog niet altijd voldoende oog is voor het feit dat mensen met een beperking uiteenlopende beperkingen kunnen hebben (fysiek, intellectueel, mentaal en zintuiglijk, vgl. art. 1 VN-verdrag Handicap) terwijl zij wel allemaal bescherming vinden onder het verdrag. Daarnaast is en blijft persoonlijke autonomie, een grondbeginsel van het verdrag (art. 3), ook in coronatijd een belangrijk element bij de juridische beoordeling van coronamaatregelen voor mensen met een beperking. Dit zijn actuele lessen, waaruit ook voor ingrijpende coronamaatregelen van latere datum lering getrokken kan worden. 